\title{
TTR
}

Traduction, terminologie, re?daction

\section{Women, Bibles, Ideologies}

\section{Luise von Flotow}

Volume 13, numéro 1, 1er semestre 2000

Idéologie et traduction

Ideology and Translation

URI : https://id.erudit.org/iderudit/037390ar

DOI : https://doi.org/10.7202/037390ar

Aller au sommaire du numéro

\section{Éditeur(s)}

Association canadienne de traductologie

ISSN

0835-8443 (imprimé)

1708-2188 (numérique)

Découvrir la revue

Citer ce document

von Flotow, L. (2000). Women, Bibles, Ideologies. TTR, 13(1), 9-20.

https://doi.org/10.7202/037390ar

\section{Résumé de l'article}

Femmes, bibles et idéologies - Julia Evelina Smith entreprit de traduire la Bible en réponse à la ferveur religieuse des adeptes de Miller vers 1840 aux États-Unis. Publiée en 1876 dans le contexte hautement politique du

mouvement des suffragettes, cette traduction eut une influence certaine sur la " Bible des femmes ". Toutefois, son approche très « littérale " a donné un texte qui ne ressemble en rien à la version " littérale " parue à la fin du XXe siècle et traduite celle-là par Mary Phil Korsak, qui appartenait à un autre mouvement idéologique.
Tous droits réservés @ C TTR: traduction, terminologie, rédaction — Les auteurs, 2000
Cecument est protégé par la loi sur le droit d'auteur. L'utilisation des services d'Érudit (y compris la reproduction) est assujettie à sa politique d'utilisation que vous pouvez consulter en ligne.

https://apropos.erudit.org/fr/usagers/politique-dutilisation/ 


\title{
Women, Bibles, Ideologies
}

\author{
Luise von Flotow
}

For about ten years in the 1830 s and 1840 s the northeastern United States was swept by a revivalist fever preparing for the Second Coming of Christ. Preacher William Miller, a farmer and gifted orator, gave hundreds of sermons on the imminent advent of Christ and the subsequent end of the world during which believers would ascend to heaven. His influence was so strong that in the fall of 1843 - he had set the date for October 23,1843 - people laid out their gowns of ascension rather than bring in their crops, expecting to see the world end before winter ${ }^{1}$.

When the Great Disappointment came and the world did not end, many of the believers suffered psychological crises and depressions, others went on to found the Church of the Seventh Day Adventists, and Julia Evelina Smith (1792-1886), a learned spinster, decided to translate the Bible in order to see where Miller had gone wrong. Subscribing to the views of the Sandemanians who believed, among other things, that the Bible could be read and understood by anyone and did not need the interpretation of a minister or church since the "bare" truth was located behind the words of the text, she wondered whether the English words Miller had relied on for his predictions had perhaps misled him. Not unaffected by the revivalist fever herself, her response to 1840 s Millerism gone awry was to learn Hebrew, perfect her Greek, and translate the entire

\footnotetext{
${ }^{1}$ My article on Julia Smith, Bible translator, will be published in French in Portraits de Traductrices, ed. Jean Delisle, University of Ottawa Press 2001.
} 
Bible as literally as possible from the original languages. In the preface to the translation published thirty years later Smith wrote that she had been

desirous to learn the exact meaning of every Greek and Hebrew word, from which King James's forty-seven translators had taken their version of the Bible.... [since] we saw by the margin that the text had not been given literally, and it was the literal meaning we were seeking (Smith, Preface 1876, my emphasis).

To arrive at this literal meaning, she wrote out the source text, "endeavouring to put the same English word for the same Hebrew or Greek word, everywhere [...]". Smith completed eight years of work on the translations in 1855 , producing several versions of both the Old and the New Testaments, each time striving to come nearer the original meaning. Her work was enhanced by regular Sunday sessions in which she, her four spinster sisters, and a free-thinking neighbour discussed what the translation had so far revealed. By the end of the project, there were 10,000 pages of closely written manuscript which were put aside for the next twenty years. It is unclear whether Smith ever found where Miller had gone wrong since neither her preface nor any other writing on the project refer to this question, and the issue may have subsided in the labour of translation. While Smith's original question may have gone unanswered, however, her translation went on to a political life of its own.

By the 1870 s, when she and one remaining sister were in their 80 s, they became the targets of a rapacious local tax collector who chose to arbitrarily raise the property taxes on their land and that of an old widow in the village. The Smiths refused to pay the tax hike, which they saw as the unjustified billing of citizens who, by reason of their sex and their civil status, were helpless in the face of lawless civil authorities. Women did not have the right to vote, and as old spinsters they did not benefit from the protection of a male voter. To collect the tax increase, the authorities auctioned off the Smiths' herd of Alderney cows as well as parcels of farm land. Insensed by continued harassment and convinced of their rights, the two octogenarian sisters began a campaign of letterwriting and public-speaking that soon made its way into the newspapers and came to the attention of the women's suffrage movement. Soon, they were travelling to speak at women's suffrage meetings throughout New England. 
After several years of lobbying, letter-writing, and public appearances including a hearing before the Senate of the United States, after further auctions of their property, and several court cases, most of which the Smith sisters lost, Julia Smith became increasingly radicalized, and decided that it might help her cause to "have it known that a woman could do more than any man has ever done", i.e. translate the entire Bible singlehandedly. She published her translation, and financed the project with her sister. The Bible came out in 1876 and was sold with special help from activist women's networks.

It is doubtful that the two old ladies ever earned back their expenses, but their publication did inspire action on another front, a much more aggressively ideological treatment of the Bible, The Woman's Bible (1895). Edited by Elizabeth Cady Stanton, one of the most vociferous and influential promoters of women's suffrage, this book consisted of a series of excerpts from the Bible which were deemed to concern women, and were accompanied by commentaries written by Bible experts, scholars, and supporters of the women's suffrage movement - mainly by Stanton herself ${ }^{2}$. A notable feature of the often caustic remarks on the roles and images assigned women in the traditional Bible is their reliance on Smith's Bible as the ultimate authority. The appendix of volume 1 of The Woman's Bible confirms the important role assigned Smith's version:

As the Revising Committee refers to a woman's translation of the Bible as their ultimate authority for the Greek, Latin and Hebrew text, a brief notice of this distinguished scholar is important: Julia Smith's translation stands out unique among all translations. It is the only one ever made by a woman, and the only one, it appears, ever made by man or woman without help (Stanton, p. 149).

\footnotetext{
${ }^{2}$ Stanton apparently had great difficulty persuading other women to participate in what was a scandalous project for the time. Feminist leaders felt the project might alienate women from the movement, and the National American Woman Suffrage Association repudiated the book when it was finally published (Simon 1996).
} 
In other words, while Stanton's Revising Committee took excerpts from the King James Bible for its work of criticism, it used Smith's translation as the final linguistic authority, trusting in her purportedly literal version rather than in the older "literary" version.

The impact that ideological and political issues had on the production and publication of this $19^{\text {th }}$ century Bible translation are relatively evident. The 1840 s context of religious excitement doubtless motivated and underlay the project ${ }^{3}$; Julia Smith's interest and disappointment in the Second Coming of Christ prompted her decision to produce a literal translation of the Bible in order to discover the truth. More importantly, Smith's belief that a literal translation was possible and would reveal the truth was motivated by a particular religious politics, the Sandemanian, and in a larger sense, the Protestant view of the Bible as a book a layperson could and should read ${ }^{4}$. Smith had been raised in a Sandemanian household where each individual was encouraged to read the Bible for themselves, and reject the mediation of any church or church-appointed official. A highly educated woman in her fifties when she started the project, she had not only read the entire Bible many times for her own edification and inspiration, but had also participated in readings and discussions of it at home, in private reading circles, among like-minded believers. Under these circumstances, it was not surprising that a gifted linguist like Smith should consider herself capable of Bible translation.

The publication of the translation occurred at an other ideological moment, when forces of conservatism and male privilege were engaged in a virulent struggle with the movement for women's suffrage. Julia Smith's position as one of the most combative and public

\footnotetext{
${ }^{3}$ Whether religious fervour is ideological may be debatable in the context of 1840s United States. In other parts of the world, it is not. However, commentators on this particular American phenomenon have pointed out how important the movement was for women; excluded from the vote and from playing active roles in politics, they were important public actors in revivalism, organizing revival meetings, preaching, and testifying (Houseley 1993).

${ }^{4}$ Sherry Simon has discussed this point in her 1987 article on Nida's translation theories.
} 
participants in this struggle clearly underlies a part of her decision to publish the work. Again, this was a decision motivated by the social, and here, political, context of the Smith sisters' struggles against unfair taxation and for women's suffrage. To choose this moment to publish a Bible that one woman alone had translated was to make a deliberate political statement, pose a further ideological challenge to the status quo.

Finally, the positive reception accorded Smith's Bible by Elizabeth Cady Stanton and her collaborators on The Woman's Bible, as well as by other women's groups, occurred in the heady context of women's political organizing. Smith's work played into the hands of forces who were able not only to support her work but use it to their own ends. And although Smith's Bible translation had been done without any feminist purposes, her achievement in some ways served the cause of suffrage and further Bible commentary from the point of view of the women's movement.

One aspect of Smith's translation that the Committee particularly appreciated could however be viewed as "feminist" in the most modern sense of the term. In Hebrew the name of the wife of Adam is "Hawwa". Smith translated this as "Life" rather than the traditional "Eve", making no comment about it in her preface. The comment in The Woman's Bible is as follows:

It is a pity that all versions of the Bible do not give this word instead of the Hebrew Eve. She was Life, the eternal mother, the first representative of the more valuable and important half of the human race. (Stanton, p. 27).

Over a hundred years later and under the aegis of another women's movement another literal translation by a woman has returned to this name "Life", justifying it in both etymological and cultural terms. In At the Start. Genesis Made New (1992) translator Mary Phil Korsak points to the fact that in Genesis 3:20 where the name "Hawwa" or "Eve" occurs for the first time, it does so in close juxtaposition with the term for "living", which is etymologically connected:

The groundling called his woman's name Hawwa for she is the mother of all hay 
The groundling called his woman's name Life (Eve)

for she is the mother of all that lives

Having shown elsewhere that popular etymology plays an important role in Hebrew naming, and that a new name is often followed by "a sentence justifying its attribution where the name is linked to what follows by a common sound" (Korsak, p. 231), Korsak chooses to translate "Hawwa" as "Life". But her reasoning goes further. She explains that the name "Hawwa" harks back to the mysterious tree in the middle of the garden of Eden, es hahyim, the tree of "life" and the tree of the knowing of good and evil, and that

when the woman takes the fruit of the tree ... she becomes life's channel, bringing within the sphere of human experience all that life represents for good and bad. The gift of life is necessarily attended by its concomitant, death (Korsak, p. 232).

Korsak is moved to point this out since more traditional translations such as Ronald Knox's 1955 version "The name which Adam gave his wife was Eve, Life, because she was the mother of all living men" focus on Eve as the mother of mankind. Yet, according to Korsak, "motherhood is not the main point of the Hebrew verse" (p. 232), the main point is "life" with all its ambiguities.

Korsak's newly literal translation of Genesis and her translator's postscript provide an interesting balance to the more strident views of Stanton's The Woman's Bible and the scholarly endeavours of Julia Smith. Yet, like the work of Smith and Stanton, and like other more recent attempts to adapt biblical texts for contemporary use in the wake of the women's movement of the late $20^{\text {th }}$ century, Korsak's work can be located in a cultural, historical, and often personal context where ideological forces clearly impact on translation. In Korsak's translation, both the contemporary women's movement and environmentalist ideas have had an impact on the work, which she readily acknowledges in her postscript. With reference to the story of the Garden of Eden, which serves as her main example in the postscript, she asserts that on the one hand, the story of the garden has "greatly influenced the concept of the status of women in society", and on the other, "other words lend themselves to an ecological interpretation" of the text (Korsak, p. 223). 
Much like Julia Smith, Mary Phil Korsak sets out to systematically use one English word for each occurrence of a certain Hebrew word. Both translators thus reject the solutions of traditional translators "who replace a single Hebrew word by a variety of English words for reasons of style or context" (Korsak, p. 225). This systematicity produces startling results in At the Start: for example, when Korsak's etymological spadework reveals that the Hebrew word "sela", commonly designating a "side" — as in "hillside" or the "side" of a tabernacle — is also the term for the part of the "adam" from which woman is created (traditionally translated as "rib"), Korsak remains consistent: "YHWH Elohim built the side /he had taken from the groundling into woman" (Korsak, p. 7). Citing rabbinical commentaries that concur with her interpretation, she concludes that "woman begins where man ends, she is his limit, and vice versa. Theirs is a side by side relationship" (p. 225).

Korsak's etymological rigour leads her to much the same conclusion as that Elizabeth Cady Stanton came to in 1895. In her commentary on the "rib" myth, Stanton writes:

There is something sublime in bringing order out of chaos; light out of darkness; giving each planet its place in the solar system; oceans and lands their limits; wholly inconsistent with a petty surgical operation to find material for the mother of the race. It is on this allegory that all the enemies of women rest their battering rams, to prove her inferiority. Accepting the view that man was prior in creation, some Scriptural writers say that as the woman was of the man, therefore her position should be one of subjection. Grant it, then as the historical fact is reversed in our day, and the man is now of the woman, shall his place be one of subjection? (p. 20).

Stanton's combative and caustic prose that contrasts the majesty of creation with the "petty surgical operation" of removing a rib derives from the same impulse as Korsak's: to reconsider the status of women in society and to establish it as equal (side by side). Yet their methods differ substantially. Korsak bases her authority on scholarly research; Stanton, taking Julia Smith's "literal" translation as her biblical reference, uses emotional political rhetoric.

Here, a question about literal translation must obviously be posed: if both Smith and Korsak claim to produce literal work, how can 
we reconcile their very different versions? Smith renders the "rib" passage:

And Jehovah God will cause a deep sleep to fall upon the man, and he will sleep;

and he will take one of his ribs and will close up the flesh underneath it. And Jehovah God will build the rib which he took from the man, into a woman, and will bring her to the man. (Smith, p. 5)

while Korsak has,

YHWH Elohim made a swoon fall upon the groundling it slept

He took one of its sides and closed up the place with flesh in its place YHWH Elohim built the side he had taken from the groundling into woman He brought her to the groundling (Korsak, p. 7)

With the exception of her translation of "Hawwa" as "Life", Smith's translation is often resolutely "patriarchal"; in this excerpt she not only maintains the "rib" but doesn't "see" that much like the translators of the King James Bible she uses one English word "man" for two Hebrew words "adam" and "ish" - a point many inclusive and feminist Bibles have paid attention to. This maintains the traditional reading that has "woman" created from "man". In this section Smith's main departure from traditional translations is in the use of tense: "God will cause a deep sleep to fall upon the man". Given Smith's interest in Millerism and the dating of the Second Coming, her focus may have been on time, and hence on tenses, and she continually produces translations of Hebrew verbs that are inconsistent with English usage. Her justification: "I think that the promiscuous use of the tenses [in Hebrew] shows that there must be something hidden, that we must search out, and not hold to the outward, for the 'letter kills, but the Spirit gives life'." (Preface) Smith's search for literal meaning is thus located elsewhere than Korsak's - and it is wise to remember that her version never aspired to any ideals of the suffrage movement or feminism; it was appropriated much later.

Korsak, on the other hand, is very much focussed on the status of women. From this position she "sees" the literal meaning of "sela" (side), and also works on the gap in meaning between "adam" and "ish". 
Korsak renders "adam" as "groundling" in the excerpt above since this creature is formed from "adamah" (the ground). She maintains this translation until after "ishah" (woman) is formed from the creature, for only then does the Hebrew text introduce the word "ish" (man). She explains: "The suggestion is that when "woman" is taken from "the groundling", "man" remains. He is, because she is, and vice versa" (p. 230). Her interest in egalitarian relations between the sexes is quite palpable here, and doubtless inspired by the ambient late $20^{\text {th }}$ century interest in this idea.

On the environmental front, the situation is similar. Smith, living the rural life of a Connecticut gentleman farmer's daughter in the 1840s, would hardly have felt the ecological/environmental urgency that motivates some of Korsak's other translations. Yet Korsak does not impose a politics of environmentalism on the text, she simply "sees" differently, still basing her decisions on etymologies and patterns of repetition. Take for example the repetition of "adam" (groundling) and "adamah" (ground) in the story of Eden:

and there was no adam to serve the adamah

But a surge went up from the earth

and gave drink to all the face of the adamah

YWHW Elohim formed the adam, soil of the adamah

He blew into his nostrils the blast of life

and the adam became a living soul

YWHW Elohim planted a garden in Eden to the east

There he set the adam he had formed

YWHW Elohim made sprout from the adamah

all trees attractive to see and good for eating (Korsak's emphasis, Postscript, p. 228)

Korsak translates "groundling" and "ground" in order to maintain this repetitive pattern and the link thus established between the creature and the ground. And she claims that this pattern also sustains two concepts: "line 1 suggests that even before it was created, the destiny of the groundling was to serve the ground"; "in line 4 there is a hint of motherearth (adamah is feminine)[...] These observations add nuance to the wellestablished view that Man was made to dominate Earth!" (228). Korsak's translation decisions go well beyond etymological or syntactic literalness: her interpretive moves are also informed by an ecological 
consciousness - a late $20^{\text {th }}$ century sense of urgency as prognoses and examples of environmental catastrophes accumulate.

While it has become a truism to state that translations are strongly affected by the ideological context of the translating culture (Lefevere 1992, Hermans 1985, Simon 1987, 1996), the picturesque story of Julia Smith's Bible translation and its influence on Stanton's The Woman's Bible, and a closer look at Mary Phil Korsak's work on Genesis present individual cases of this translation effect in the sensitive field of Bible translations by women. Smith's interest in the revivalist fervour and Sandemanian views of Bible interpretation, and her publication in the wake of perceived political injustices, clearly restate the issues. Stanton's focus on the Bible as a political instrument for the subjugation, but also the liberation, of women from the yoke of traditional male denigration, though not a translation, is an ideological re-writing of the text. Finally, Korsak's feminist and environmentalist focus clearly comes out of two of the more important social movements of the late $20^{\text {th }}$ century.

In translation, the translator's "positionality" is undeniable 5 . The translator writes from a specific moment, from within a specific culture and usually sub-culture, and often in dialogue with the social and political culture of the moment. Inevitably, there is an ideological slant on the texts. This is why literal translation, word for word translation in the 1840 s reveals other "truths" than a similar approach in the 1990s. Julia Smith saw the connection between "Hawwa" and "Life", but looked no further at the time of the translation. Had she done the work in the $1870 \mathrm{~s}$ after her exposure to the suffrage movement, she may well have taken the more radical stance that Stanton and the committee of The Woman's Bible adopted. Korsak's work, on the other hand, published after more than twenty years of feminist and environmental lobbying, not only sees the "Hawwa/Life" connection but comments on it insightfully.

\section{University of Ottawa}

\footnotetext{
'I have discussed the importance of this "positionality' in regard to the politics of the women's movement and translation in "Dis-unity and Diversity. Feminist Approaches to Translation Studies", in Unity in Diversity. Current Trends in Translation Studies (1998).
} 


\section{Works Cited}

FLOTOW, Luise von (1998). "Dis-Unity and Diversity. Feminist Approaches to Translation Studies", Unity in Diversity? Current Trends in Translation Studies, ed. Lynne Bowker, Michael Cronin, Dorothy Kenney and Jennifer Pearson. Manchester, St. Jerome Publishing, pp. 314.

HERMANS, Theo (ed.) (1985). The Manipulation of Literature: Studies in Literary Translation. New York, St. Martin's Press.

KORSAK, Mary Phil (1992). At the Start. Genesis Made New. A Translation of the Hebrew Text. New York/London, Doubleday.

LEFEVERE, Andre (1992). Translation, Rewriting and the Manipulation of Literary Fame. London and New York, Routledge.

SIMON, Sherry (1987). "Délivrer la Bible: La théorie d'Eugène Nida", Meta, XXXII, 4, pp. 429-437.

- (1996). Gender in Translation. Cultural Identity and the Politics of Transmission. London and New York, Routledge.

SMITH, Julia, (tr.) (1876). Holy Bible containing the Old and New Testaments: translated literally from the original tongues. Hartford, Conn., American Publishing Company.

STANTON, Elizabeth Cady (1985). The Woman's Bible. Introduction by Dale Spender, Part 1 first published 1895, Part 2 published 1898 by European Publishing Company, New York. Edinburgh, Polygon Books.

\section{Works Consulted}

HOUSELY, Kathleen (1988). "The Letter Kills but the Spirit Gives Life", Julia Smith's Translation of the Bible", The New England Quarterly, vol. LXI, no. 4, pp. 555-568. 
- (1993). The Letter Kills but the Spirit Gives Life. Glastonbury, Historical Society of Glastonbury.

SHAW, Susan (1993). A Religious History of Julia Evelina Smith's 1876 Translation of the Holy Bible. Doing More than Any Man Has Ever Done. San Francisco, Mellen Research University Press.

SPEARE, Elizabeth G (1957). "Abby, Julia and the Cows", American Heritage, vol. VIII, no. 4, pp. 54-58.

ABSTRACT : Women, Bibles, Ideologies - Julia Evelina Smith's Bible translation was undertaken in response to the religious fervour of the Millerites in 1840s USA. Published in 1876, in the highly politicized context of the women's suffrage movement, it influenced "The Woman's Bible" (1895). Yet its "literal" approach results in a text that is quite unlike a late $20^{\text {th }}$ century "literal" version by Mary Phil Korsak from yet another ideological movement.

RÉSUMÉ : Femmes, bibles et idéologies - Julia Evelina Smith entreprit de traduire la Bible en réponse à la ferveur religieuse des adeptes de Miller vers 1840 aux États-Unis. Publiée en 1876 dans le contexte hautement politique du mouvement des suffragettes, cette traduction eut une influence certaine sur la "Bible des femmes ». Toutefois, son approche très « littérale " a donné un texte qui ne ressemble en rien à la version " littérale " parue à la fin du $\mathrm{XX}^{\mathrm{e}}$ siècle et traduite celle-là par Mary Phil Korsak, qui appartenait à un autre mouvement idéologique.

Key Words : Bible translation, feminism in translation, translation and religion, translation and politics, translation and women's suffrage.

Mots-clés : Bible et traduction, le féminisme en traduction, traduction et religion, traduction et politique, la traduction et le suffrage des femmes.

Luise von Flotow: University of Ottawa, School of Translation, 70 Laurier Avenue East, Ottawa (Ontario) K1N 6N5

E-mail: vonfloto@uottawa.ca 